\title{
Historical
}

\section{Lewis and Clark, Pioneering Rangeland Managers?}

\section{By Richard H. Hart}

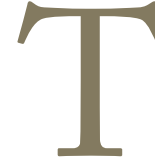

wo hundred years ago, the "Corps of Discovery," as the expedition led by Meriwether Lewis and William Clark was formally known, was well into the Northern Great Plains. They were not the first Euro-Americans to enter this region. Henry Kelsey had been on the Saskatchewan River in 1690 or 1691 and described his travels in verse of awkward rhyme and worse meter. ${ }^{1}$ Pierre Gaultier de Varennes, Sieur de la Vèrendrye, reached the Mandan villages on the Missouri River in 1738. His sons, Louis-Joseph and François, traveled up the Missouri from the villages in 1742 and 1743, reaching the mouth of the Teton River. ${ }^{2}$ DeVoto describes several other explorations of the Northern Plains before 1800. ${ }^{3}$ Representatives of the Hudson's Bay Company and the North West Company had been trading with the Mandan villages for decades before the appearance of Lewis and Clark, ${ }^{3}$ and several had left journals. ${ }^{4}$ However, none of them showed any interest in the agricultural or stock-raising potential of the Plains.

Curiously, neither did Lewis and Clark. Their primary objective was to discover the shortest route between the headwaters of the Missouri and Columbia rivers. They were also to determine the northernmost reach of the Missouri drainage; to assert American sovereignty over the West and proclaim American authority over its Indian tribes and British traders; and to add to the knowledge of the plants and animals, weather, seasons, and natural wealth of the region. Although this knowledge might be of use in establishing agriculture in the West, this objective was not stated specifically.

In their journals, Lewis and Clark ${ }^{5,6}$ continually express astonishment at the immense herds of grazing animals on the Northern Plains. On April 22, 1805, Lewis described "immence herds of Buffaloe, Elk, deer, \& Antelopes feeding in one common and boundless pasture" ${ }^{6}$ near the present Williston, North Dakota (p. 60). On August 29, 1806, near the mouth of White River, Clark wrote: "I had a view of a greater number of buffalow than I had ever seen before at one time. I must have seen near 20,000" (p. 238). ${ }^{6}$

However, neither Lewis nor Clark made the connection that rangeland that could support such masses of bison could also support large numbers of domestic livestock. On the other hand, Steven Long ${ }^{7}$ and John C. Fremont ${ }^{8}$ concluded that, although the Great Plains were unfit for crop agriculture, they were excellent grazing lands. However, Lewis and Clark's sighting of large numbers of bison nearly every day and of bison on 19 of the 29 days they spent near the Great Falls of the Missouri casts doubt on the regular migration of bison and the rationale for rotational grazing. ${ }^{9}$

Although they frequently mentioned woody vegetation and the more showy forbs, Lewis and Clark rarely mentioned grass in general, and never, as far as I could find, mentioned a particular species of grass. Perhaps they viewed grass as outside the plant kingdom, as Fremont ${ }^{8}$ apparently did when he recorded “... hunting plants among the grass" (p. 33). Lewis did complain about the abundance of prickly pear: "The prickly pear is now in full blume and forms one of the beauties as well as the greatest pests of the plains" (p. 383). ${ }^{6}$

Although Lewis and Clark were truly pioneering naturalists, ${ }^{10}$ we must conclude they were not pioneering rangeland managers. This is not so strange, considering that our profession is a relatively new one; the Society for Range Management is 60 years old.

Author is a retired Rangeland Scientist with 39 years of service with the Agricultural Research Service, US Department of Agriculture. For the last 27 years of his career, he conducted grazing management and rangeland ecology research at the High Plains Grasslands Research Station, Cheyenne, WY. Now he dabbles in Western history and writes and recites cowboy poetry. He can be contacted at 7132 Cordova Drive, Cheyenne, WY 82009, or atdickhart@aol.com.

\section{References}

1. EPP, H. T. [ed.]. 1993. Three hundred prairie years: Henry Kelsey's "Inland country of good report." Regina, Saskatchewan: Canada Plains Research Center.

2. Brebner, J. B. 1933. The explorers of North America. New York, NY: Macmillan Company. 
3. DeVoto, B. 1952. The course of empire. Boston, MA: Houghton Mifflin Company.

4. Wood, W. R., AND T. D. ThiEssen [eds.]. 1985. Early fur trade on the Northern Plains: The narratives of John MacDonnell, David Thompson, Francois Antoine Larocque, and Charles McKenzie. Norman, OK: University of Oklahoma Press.

5. DeVoto, B. [ed.]. 1953. The journals of Lewis and Clark. Boston, MA: Houghton Mifflin Company.

6. Moulton, G. E., and T. W. Dunlay [eds.]. 1983-2001. The journals of the Lewis \& Clark Expedition. Lincoln, NE: University of Nebraska Press.
7. James, E. 1823. Account of an expedition from Pittsburgh to the Rocky Mountains. Performed in the Years 1819, 1820, vol. XIV-XVII. In: R. G. Thwaites [ed.]. Early western travels, 1748-1846. Cleveland, OH: Arthur H. Clark Company.

8. FrEmont, J. C. 1845. Report of the exploring expedition to the Rocky Mountains in the year 1842, and to Oregon and North California in the years 1843-44. Washington, DC: Gales \& Seaton.

9. HART, R. H. 2001. Where the buffalo roamed-or did they? Great Plains Research 11:83-102.

10. Cutright, P. R. 1969. Lewis and Clark, pioneering naturalists. Urbana, IL: University of Illinois Press. 